\title{
RAMAH LINGKUNGAN DEMI MENJAGA KESEIMBANGAN ALAM (MORAL TERHADAP ALAM SEMESTA)
}

\author{
Oleh: \\ Joko Wahono \\ Universitas Cokroaminoto Yogyakarta
}

\begin{abstract}
Abstrak
- Seiring dengan berjalannya waktu, perkembangan dunia dan tuntutan kebutuhan manusia mengalami peningkatan pesat. Di sisi lain usia bumi dan alam yang menyediakan semua bahan kebutuhan manusia juga mengalami penuaan. Mengingat semua kepentingan tersebut maka manusia harus memperhatikan kelesterian alam agar ketersediaan bahan kebutuhan hidupnya tercukupi. Oleh karena itu, kehidupan yang ramah lingkungan adalah salah satu jawaban untuk menghadapi masalah tersebut.Konsep ramah lingkungan adalah satu konsep solusi untuk penghematan dan pengurangan limbah hasil industri global yang mungkin dapat memberi dampak negatif terhadap kelestarian alam. Padahal lestarinya alam semesta adalah demi kepentingan dan kelangsungan hidup di masa datang, untuk generasi mendatang. Salah satu konsep pelestarian adalah dengan menjaga ekosistem air yang merupakan sumber kehidupan utama bagi manusia dan makhluk lain di sekitarnya. Dengan konsep hidup ramah lingkungan, maka kita telah memberi kontribusi bagi kelangsungan hidup generasi masa datang. Oleh karena itu, semua komponen masyarakat hendaknya mempunyai kepedulian akan hal ini. Menjaga ekosistem air, berarti kita memperpanjang usia bumi dan generasi berikutnya.
\end{abstract}

Kata Kunci: Rumah Lingkungan, Keseimbangan Alam

\section{Pendahuluan}

Konsep utama manusia di ciptakan Allah adalah untuk menjalani ujian sebagai wakilnya Allah untuk menciptakan kesejahteraan di bumi. Bukan hanya untuk kesejahteraan diri sendiri, namun kesejahteraan untuk manusia dan makhluk yang lainnya. Kalau kita memahaami alasan Allah menciptakan bumi dengan segala isinya ini tentunya dilandasi rasa kasih sayang Nya kepada manusia. Sehingga Allah berkenan menyediakan segala aspek kebutuhan hidup manusia. Maka bagi manusia yang berfikir, sudah selayaknyalah mereka berfikir untuk mensyukuri segala pemberian itu. Pemberian fasilitas yang demikian inilah yang Allah tidak pernah menuntut balasan apapun. Hanya meminta manusia tunduk dan patuh dengan segala 
perintahnya menurut batas kemampuan manusia itu sendiri. Allah tak pernah menuntut sesuatu yang diluar batas kemampuannya.

Allah menciptakan bumi dengan segala isinya adalah sebagai materi ujian buat manusia yang di tunjuk sebagai khalifah (wakil) Nya. Allah hanya mengamanati agar kita berlaku adil terhadap alam untuk kepentingan sesama manusia. Nah, kalau kita semua berlaku boros bahkan telah berani mengeksplorai alam ini secara asal-asalan tanpa memikirkan dampak pada lingkungannya, maka kita telah melalaikan amanat Allah tersebut. Dengan perilaku yang demikian berarti kita telah melakukan kedzaliman berlapis. Pertama, kita telah dzalim kepada Allah yang elah memberi amanat besar untuk membawa kebaikan di bumi dalam rangka menciptakan kesejahteraan di sini. Kedua, kita dzalim kepada sesama manusia dimana kita hanya mementingkan kebutuhan hidup diri sendiri saat ini tanpa memikirkan kebutuhan hidup manusia di masa datang. Ketiga, kita dzalim kepada alam semesta ksrena kita telah merusak dan mengabaikan kelestariannya. Dengan mengingat betapa tingginya nilai amanah dari Allah tersebut, maka sudah selayaknya kita membuktikan jika kita mampu melaksanakan amanh tersebut. Allah telah membuat kita bahagia, tentu kita berkeinginan membuat Allah menjadi senang. Untuk itu kita harus pandai menjaga dan melestarikan semua fasilitas Allah melalui alam ini. Sumber-sumber hewani maupun nabati, sumber-sumber mineral, logam dan bebatuan. Adalah kewajiban kita untuk menjaganya. Diantara sumber daya alam yang harus kita utamakan penjagaannya adalah sumber daya alam air, baik air yang ada di permukaan bumi maupun yang terdapat di dalam bumi. Air telah dikodrtakan oleh Nya sebagai sumber kehidupan utama setelah udara. Dengan memelihara sumber daya air berarti kita telah memlihara sumber kehidupan diri kita sendiri dan makhluk lainnya di bumi ini. Sebaliknya, dengan kita mengabaikan dan merusak sumber daya air, berarti kita telah mengabaikan dan merusak sumber kehidupan makhluk hidup. Kalau kita tidak memelihara sejak sekarang maka tak ada lagi harapan kehidupan bagi generasi kita selanjutnya. Oleh karena itu, Allah pun tidak menyia-nyiakan manusia yang telah memelihara sumber daya alam di bumi ini dengan memberikan pahala untuk kehidupan di akhirat sekaligus memberikan kebaikan dalam kehidupan di dunia.

Orang yang menjaga alam, pasti akan terjaga hidupnya. Orang yang memelihara alam pasti akan terpelihara hidupnya. Demikianlah janji Allah kepada hamba yang senantiasa mengharap keridlaan Nya. Maka Allahpun berpesan, barangsiapa beriman kepada Allah dan hari akhir berbuat baiklah kepada sesama. Baik sesama manusia, binatang, tumbuhan dan makhluk 
Allah lainnya di muka bumi ini agar kita tetap di beri kebaikan dunia dan akhirat oleh Allah SWT.

\section{Sebuah Landasan Teleologis}

Perhatikanlah dialog Allah SWT di hadapan para malaikat dan jin ketika Allah menyampaikan kehendaknya untuk mencipta manusia sebagai khlaifah di muka bumi.

\section{Allah : "Sesungguh Aku akan mencipta di muka bumi seorang khalifah (manusia)}

Malaikat : "Akankah Engkau mencipta makhluk yang akan membuat kerusakan dan bahkan pertumbpahan darah di muka bumi ?"

Allah : "Sesungguhnya engkau tidak mengetahui apa yang Aku ketahui."

Melihat dialog di atas, sesungguhnya malaikat iu sudah meragukan kemampuan manusia untuk menjaga bumi dan seisinya. Namun karena jaminan yang di berikan oleh Allah sehingga malaikatpun akhirnya tunduk dengan perintah Nya itu. Salah satu jaminan Allah pada manusia adalah dengan diberikannya akal (hati nurani) pada manusia. Dengan akal dan hati nuraninya di harapkan manusia mampu mengendalikan perilakunya dengan mempertimbangkan sesuatu yang baik dan yang buruk. Dengan pertimbangan itu maka manusia di harapkan dapat memilih dan menentukan sesuatu mana yang harus di lakukan dan mana yang tidak harus dilakukan.

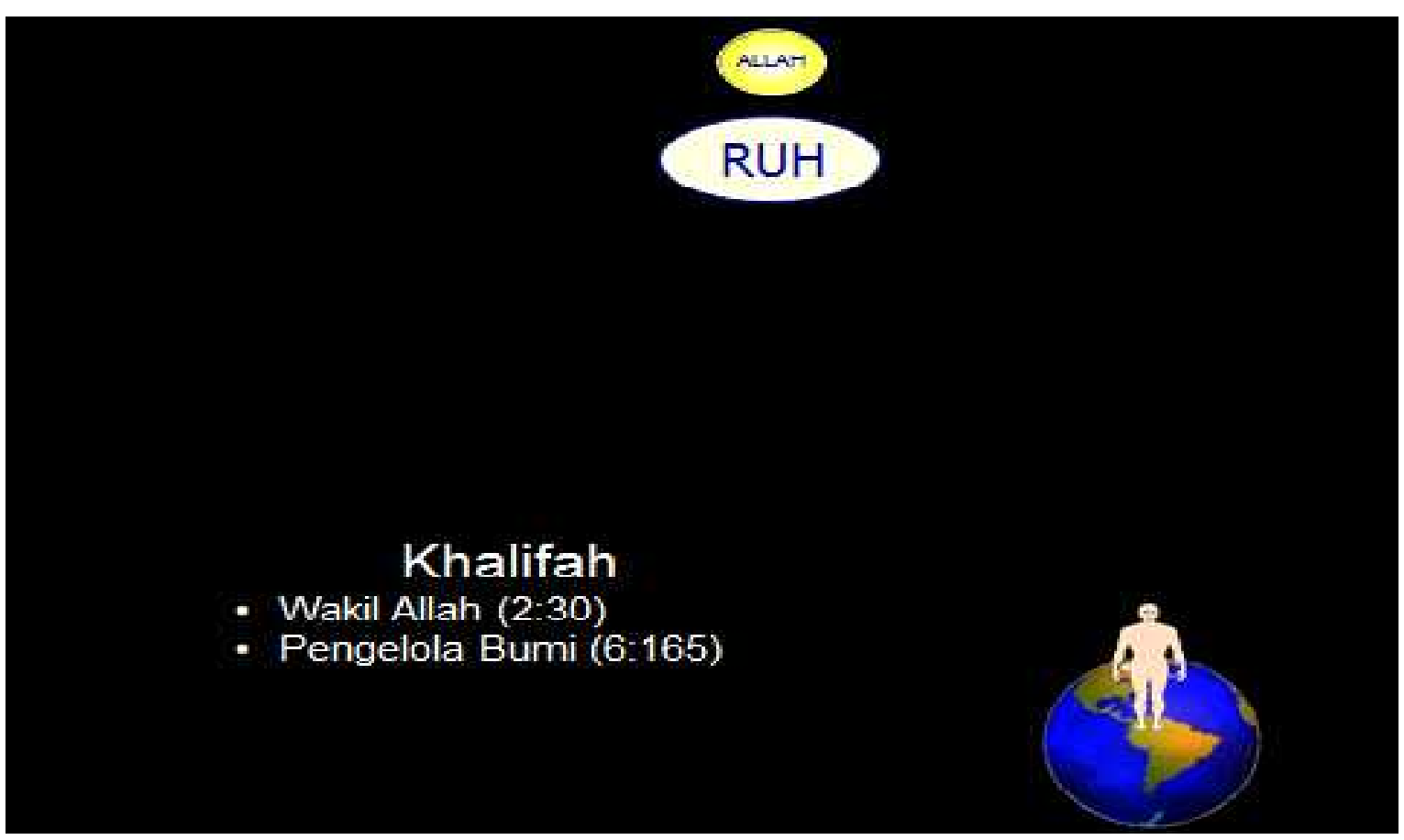


Berdasar pada skema di atas, Allah telah merancang jauh-jauh tentang siapa yang akan dipilih menjadi khalifahnya di muka bumi nanti. Manusia yang dicipta bermula dari Ruuh, yang kemudian diberi jasad / raga sebagai cassing agar mampu bekerja dengan baik di muka bumi mewakili kehendak Allah. Tentunya rancangan Allah ini tidak sembarangan. Hal itu terbukti betapa Allah telah menyempurnakan setiap organ tubuh ini dengan segala fungsi dan kemampuannya untuk memangku tugas berat sebagai khalifah. Di dalam jasad itu kemudian ruh / jiwa itu di semayamkan agar mampu mengonsep kehendak melalui hati nuraninya agar langkah-langka yang di lakukan manusia selalu dalam kebaikan. Namun sayang, bahwa di dalam jasad itu pula tersembunyi sebua Hawa (Desire) yang mendorong manusia pada kecenderungankecenderungan tertentu. Bah jika kecenderungan ini tidak terkendali, seringkali inilah yang menyebabkan dorongan perbuatan yang membawa kerusakan. Dorongan inilah yang kemudian disebut dengan hawa nafsu.

Jika yang dominan pada manusia adalah akal (qalbu) nya, maka niscaya akan menuntun pada kebaikan, akan tetapi jika yang dominan adalah hawa nafsunya maka sudah dapat dipastikan perbuatannya akan menuju pada kerusakan. Ketika malaikat mengingat akal yang diberikan pada manusia, maka merekapun optimis manusia akan bisa mewujudkan kesejaheraan di bumi. Namun ketika mengingat hawa nafsu yang di berikan pada manusia, maka sesungguhnya malaikat itu pesimis akan kemmpuan manusia di muka bumi. Di dalam diri manusia telah dipenuhi dengan fasilitas diri yang begitu sempurna. Di sisi yang lain, bumi dan segala isinya juga merupakan fasilitas dan anugerah sempurna buat manusia. Di permukaan dan di dalam bumi ini telah tersedia segala aspek kebutuhan manusia. Dari aspek kebutuhan yang bersifat universal seperti udara, cahaya, air tumbuhan yang tersedia, ada pula jenis ketersediaan bahan - bahan yang dapat diolah oleh manusia itu sendiri untuk memenuhi kebutuhan hidupnya. Dari olahan kayu, batu maupun sumber-sumber alam lainnya. Singkatnya Allah telah menyediakan semua itu untuk dikelola oleh manusia tanpa imbalan apapun yang harus di berikan untuk Allah. Allah hanya menghendaki ibadah (pelayanan) manusia untuk sesama dan kebaikan alam semesta. 


\section{Alasan Allah Menciptakan Alam Semesta}

Sehubungan dengan hal ihwal penciptaan bumi, tentu Allah telah memiliki rancangan dan alasan yang tepat hingga kenapa Allah menciptakannya sedemikian rupa. Sebagai dasar pemahaman kita, kiranya dapat dicermati ayat berikut ini :

“Wahai manusia sembahlah Tuhanmu yang telah menciptakanmu dan orang-orang sebelum kamu, agar kamu sekalian bertaqwa. Dialah yang menciptakan bumi sebagai hamparan bagimu dan langit sebagai atap,dan Dia menurunkan air (hujan) dari langit, lalu Dia menhasilkan dari hujan itu berbagai macam buah-buahan sebagai rizki bagimu,oleh karena itu janganlah kau jadikan sekutu-sekutu bagi Allah, sedangkan kamu mengetahui.” (QS Al Baqarah (2) : 21 - 22).

Berdasarkan ayat di atas seharusnya sudah cukup bagi kita untuk memahami tentang bagaimana islam memandang alam sebagai nikmat dari Allah SWT. Allah sebagai Rabbul 'Alamin telah berkenan menciptakan alam semesta ini sebagai bentuk pelayanan Nya kepada manusia yang telah di rancang untuk mewakilinya dalam hal pengelolaannya. Maka dari itu, Allahpun konsekuen untuk memenuhi segala aspek kebutuhan manusia itu sendiri. Allah turunkan hujan di atas bumi yang telah dihamparkan oleh Allah sebagai tempat tinggalnya manusia. Dari air hujan itu segala tumbuhan dapat berbuah dan berkembang biak. Hal itu semata-mata hanya untuk kepentingan hidup manusia dari masa ke masa. Di sisi yang lain, manusia menerima amanah yang berupa semua pemberian itu untuk dikelola dengan sebaikbaiknya. Jangan sembarangan mengelola dan mengeksplorasi, karena kita masih punya nank cucu yang akan hidup di masa mendatang. Hematlah penggunaan sumber daya alam. Olah limbahnya jangan sampai mengakibatkan kerugian bahkan kepunahan generasi mendatang. Ingat ini adalah amanat besar dari Allah. Barangsiapa mampu menjaga amanat ini, sudah barang tentu Allahpun akan ridla kepada kita. Di dalam al quran ada ayat yang menyebutkan "Laa tufsidhuu fil ardli ba'da ishlahiha” yang artinya “ Janganlah merusak alam ini, merusak bumi ini setelah ditata dengan sedemikian baik “. Berdasarkan perintah al quran di atas, maka menurut teori orang sekarang KESEIMBANGAN ALAM adalah jawabannya. Keseimbangan itulah yang di maksud dengan bakda ishlaliha sebagaimana tertera pada ayat di atas. Jadi kalau bicara soal lingkungan alam dan bagaimana semestinya bertindak terhadap alam, islam suda membicarakan dan mengaturnya sejak awal. Sedangkan dunia barat baru sibuk membicarakan penataan alam ini di penghujung abad ke-20, itupun karena mereka telah merusaknya lebih dahulu. Sungguh sangat ironis apa-apa yang telah dilakukan manusia di muka bumi ini.

Di dalam ayat yang lain Allah juga telah berfirman sebagai berikut : 
Dan janganlah kamu berbuat kerusakan di bumi ini, setelah (Allah) memperbaiki. Berdoalah kepada Nya dengan penuh rasa takut (tidak akan dierima) dan penuh harap (agar dikabulkan). Sesungguhnya rahmat Allah amat dekat dengan orang-orang yang berbuat kebaikan. (QS Al A'raf (7) : 56).

Demikianlah Allah telah menciptakan dan mengatur bumi ini dengan aturan yang baik. Jika tidak ingin terjadi kerusakan, maka hendaknya manusia mematuhi aturan Allah tersebut. Namun sebaliknya, jika manusia tidak mematuhi aturan tersebut sudah barang tentu akan terjadi kerusakan yang dahsyat di muka bumi ini akibat ulah manusia itu sendiri.

\section{Gambaran Kerusakan Akibat Ulah Manusia}

Berikut ini akan di sampaiakan berbagai peristiwa bencana yanag melanda tanah air kita. Di sinyalir semua itu akibat ulah manusia sendiri karena telah merusak keseimbangan alam itu sendiri. Di sebabkan oleh eksplorasi alam yang tidak terencana maka dampak alam pun menimpa manusia itu sendiri. Pada satu dekade terjadi banjir bandang menerjang wilayah kalimantan, setelah sebelumnya banjir yang lebih dahsyat melanda kawasan Blitar, Jawa Timur. Ratusan rumah dan bangunan penting pemerintah porak poranda akibat bencana itu. Tidak sedikit warga yang akhirnya harus menderita karena kehilangan tempat tinggal, sumber rejeki, bahkan kehilangan jiwa diantara anggota keluarganya. Juga wilayah Aceh pasca ditimpa gempa dan tsunami, pun ikut terendam banjir. Bahkan di Jakarta banjir selalu terjadi pada setiap tahun. Semua malapetaka ini terjadi akibat rusaknya ekositem alam yang tak lagi ada keseimbangan padanya. Krisis ekologi ini akibat ulah tangan-tangan rakus manusia yang mengeksploitasi alam secara asal-asalan tanpa memperhatikan kerusakan dan akibat yang ditimbulkannya. Mengingat dahsyatnya kerusakan akibat ulah manusia seperti yang di gambarkan di atas, perlulah kiranya di atur undang-undang yang jelas bagi warga negara terhadap ekologi sekitarnya. Bahkan perlu juga di rumuskan Fiqih Lingkungan (Fiqh $\mathrm{Al} \mathrm{Bi}$ 'ah) yang merupakan kebutuhan yang tidak bisa ditawar-tawar lagi yang merupakan suatu keharusan. Yaitu sebuah fiqih yang yang menjelaska aturan tentang perilaku ekologis masyarakat muslim ( Ecology Wisdom ) berdasarkan teks syar'i yang bertujuan untuk mencapai kemaslahatan dan melestarikan lingkungan. 


\section{Bagaimana Merawat Ekologi di muka} Bumi

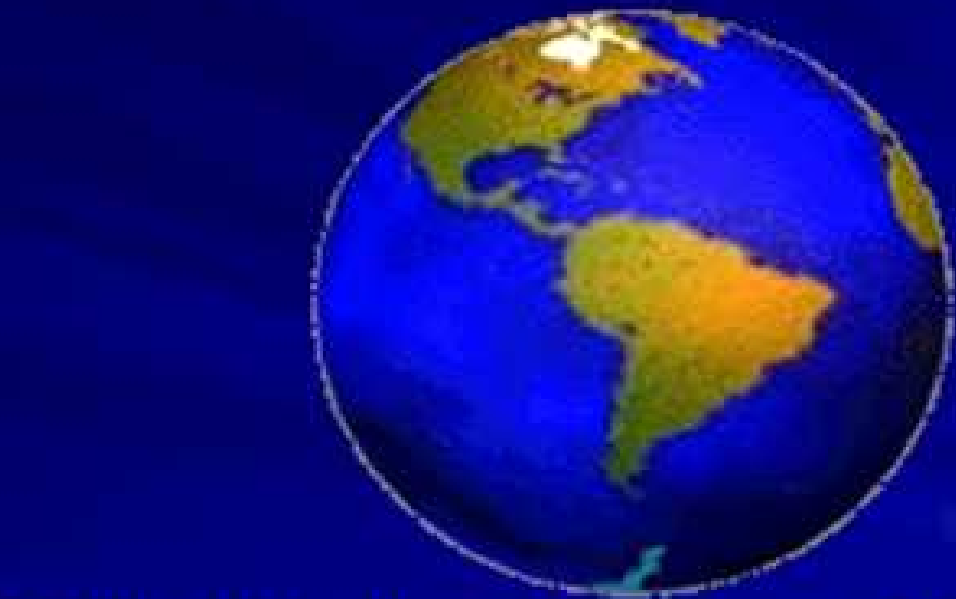

\section{Allah ciptakan bumi dan isinya untuk memenuhi} kebutuhan manusia

Setiap lapis yang ada di bumi terdapat materi-materi yang berguna bagi kehidupan manusia itu sendiri. Sebagaimana Allah telah menjelaskan dalam firman Nya, bahwa Dialah Allah yang telah menciptakan bumi ini menjadi tujuh lapisan, demikian pula langit yang ada di atas kiat, juga di ciptakan Allah dalam tujuh lapisan. Dari seluruh lapisan itu Allah hidupkan organ-organ alamiah yang dapat memberikan kegunaan bagi kehidupan manusia. Kalau kita belah bumi ini dan kita lihat lapisannya. Maka dari lapisan permukaan hingga ke dalam bumi akan kita jumpai kekayaan alami yang tidak ternilai harganya. Semua itu Allah berikan dengan Cuma-Cuma. Maka sungguh tidak pantas jika manusia menggunakannya secara asal-asalan, eksploitasinya tanpa perencanaan, dan penggunaanya secara boros tanpa mempedulikan dan memperhatikan kepentingan generasi di masa datang. Terhadap orang-orang seperti ini tentunya Allah tidak akan ridla. Oleh karena itu perlakukanlah alam ini secara adil dan seimbang, karena alamlah yang telah menyediakan kebutuhan kita. Mari kita coba pikirkan ketersediaan sumber kehidupan yang disediakan Allah di permukaan bumi, di sana terdapat sumber daya air, baik air sungai, danau dan lautan. Di sana dapat hidup ekosistem air baik hewani maupun nabati. Di permukaan bumi tumbuh pula berjuta-juta jenis tanaman dari ukuran kecil hingga yang besar. Dari padanya dapat hidup ekosistem darat baik hewani maupun nabati. Sumber buah-buahan dan 
tanaman pangan dapat di hasilkan di sisni. Singkat kata segala sumber alam yang ada tersedia dan sengaja ditundukkan oleh Allah untuk memenuhi kebutuhan manusia. Pada bagian perut bumi terdapat magma, bijih besi dan logam lainnya, tersimpan batu-batu yang bernilai tinggi, berbagai kandungan minyak dan gas, sumber air dan sungai di bawah tanahpun ada, Dan semua jenis karakter lapisan tanah di dalamnya dapat menjadi tempat kehidupan ekosistem tanah yang tak pernah kita membayangkan betapa besar nilainya. Perhatikan skema belahan tanah berikut ini, dan bayangkan betapa besar nilai sumber daya alam yang terkandung di dalamnya, dan semua itu tersedia untuk memenuhi sumber kehidupan manusia itu sendiri.
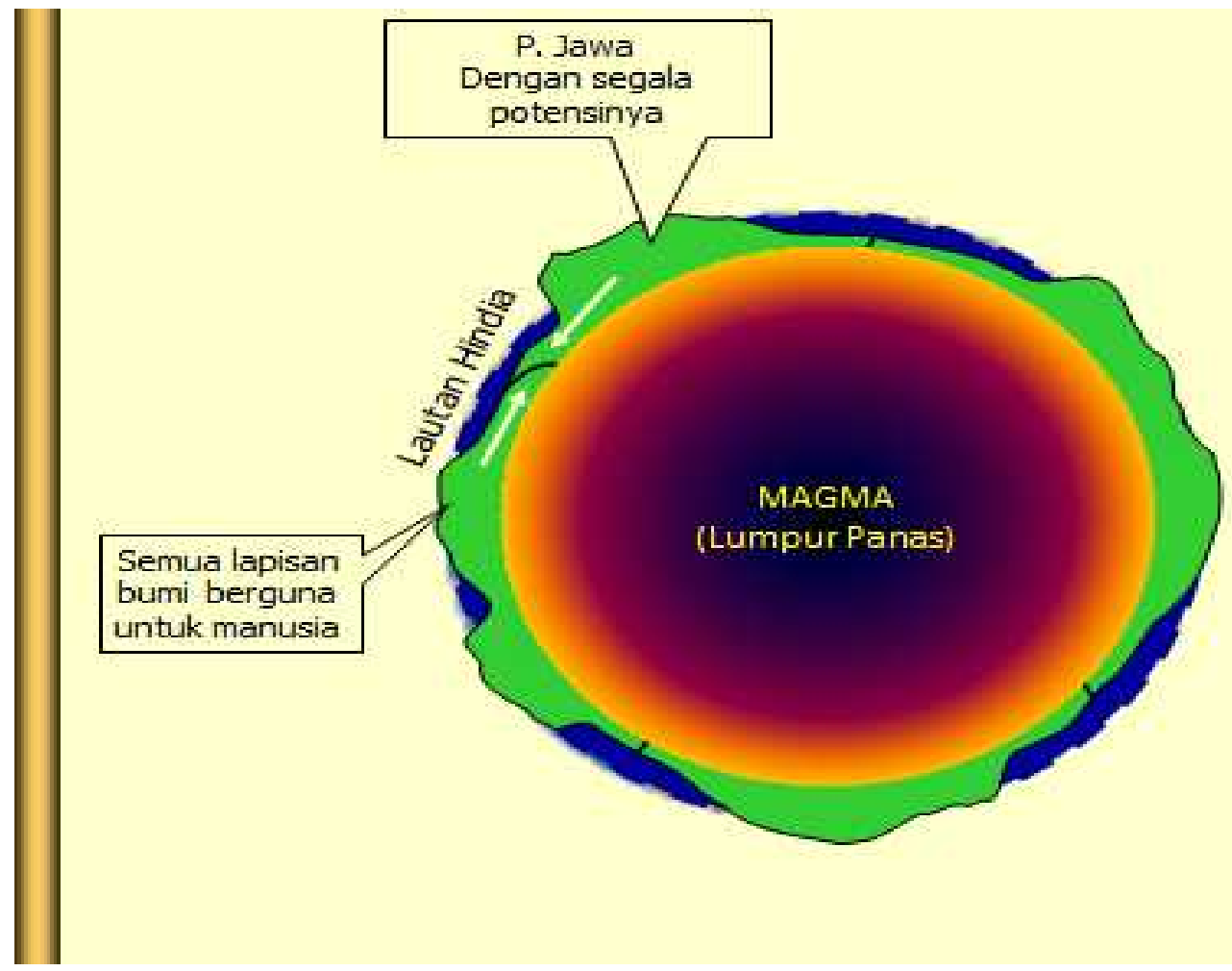

Bagi orang-orang yang beriman dan beakal tentu hal ini akan membuat hatinya bersyukur dan tindakannya tak ngawur, karena Allah ciptakan ini semua sebagai wujud kasih sayangnya pada manusia sebagai khalifah Nya. Perhatikan firman Allah berikut ini :

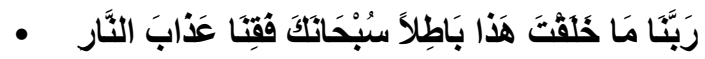

"Yaa Tuhan kami, tidaklah Engkau ciptakan semua ini dengan sia-sia, Maha Suci Engkau, dan jauhkan kami dari siksa api neraka.” (QS. Ali Imran (3) : 191). 


\section{Kesimpulan}

Betapa besar kecintaan Allah kepada manusia yang telah mencipkaan alam semesta ini ditundukkan untuk kepentingan manusia. Semua potensi alam ini di berikan secara cuma-Cuma untuk memenuhi kebutuhan manusia itu sendiri. Terlebih bagi bangsa Indonesia telah mengkaruniai iklim yang begitu indah dan subur, sehingga kekayaan alam di Indonesia ini tiada duanya di dunia ini. Dengan iklim tropis, menjadikan potensi bumi Indonesia menghasilkan sesuatu yang paling menguntungkan bagi penduduknya.Dengan kondisi geografis yang bersifat agraris dan kepulauan ini, maka menjadikan hasil bumi dan budidaya laut di Indonesia sangatlah melimpah. Banyaknya gunung berapi yang aktif menjadikan tanahnya subur dan limpahan material yang tak ternilai harganya. Banyaknya pegunungan yang ada mampu menyimapan sumber daya air mineral yang melimpah dan sangat bermanfaat bagi kehidupan. Luasnya hutan merupakan sumber kekayaan tersendiri yang merupakan aset jangka panjang bagi generasi mendatang. Singkat kata, seluruh potensi alam Indonesia dapat di katakan surga dunia bagi para penduduknya. Jika seluruh penduduk Indonesia mampu menjaga dan mengelola amanat dari Tuhan yang berupa ekologi yang telah dikaruniakan, tak ayal negeri ini akan menjadi negeri terkaya di dunia ini. Kebutuhan rakyatnya akan terpenuhi, karena Allahpun telah memberikan seluruh aspek kebutuhan manusia telah ada di Indonesia ini. Sebagai kata penutup, marilah kita bersama-sama menjaga ekologi di sekeliling kita agar kebutuhan hidup tetap terpenuhi dan kehidupan generasi mendatang tetap tersedia. Dan akhirnya ridla dan nikmat Allah akan selalu di berikan untuk bangsa Indonesia.

\section{Daftar Pustaka}

Al Hikmah, AlQuran dan Terjemahnya, Departemen Agama RI, Yayasan Penyelenggara Penterjemah Al Quran, Lajnah Pentasih Mushaf Al Quran, CV Diponegoro, Bandung, 2005.

Muntakhab Ahadits, Syaikh Maulana Muhammad Yusuf, Ash Shaff, Yogyakarta, 2007.

Hukum Islam, Prof. H. Mohammad Daud Ali, SH, PT Raja Grafindo Persada, Depok, 2014.

Filsfat Ilmu, Dr. Suwardi Endraswara, M.Hum, C A P S, Yogyakarta, 2012.

Lentera Qolbu, Ahmas Fais Asifuddin, Pondok Pesantren Imam Bukhori, Sukoharjo, 2015. 